\title{
HUMAN CHORIONIC GONADOTROPHIN: COMPARATIVE STUDIES OF OVARIAN UPTAKE IN MAMMALS*
}

\author{
Gerald J. Mizejewski $\dagger$ \\ Department of Biology, University of South Carolina 29208 and \\ Veteran's Administration Hospital, University of Michigan Medical Center,
} Ann Arbor, MI 48105, U.S.A.

(Received 26 July 1974)

\begin{abstract}
The localization of radiolabeled human chorionic gonadotrophin $\left({ }^{125} \mathrm{I}-\mathrm{HCG}\right)$ was studied in a number of commonly used mammalian animal models.

2. The ovary proved to be the target organ for ${ }^{125} \mathrm{I}-\mathrm{HCG}$ in all animals studied.

3. The optimum time for the localization of HCG in the ovary varied in all the mammals extending from 1.5 to $4 \mathrm{hr}$.

4. HCG is apparently used in the target cell for only a brief period and is excreted rapidly as indicated by renal uptake levels.

5. All other female organs and tissues failed to display any affinity for HCG.

6. The affinity of ${ }^{123} \mathrm{I}-\mathrm{HCG}$ for the various mammalian ovaries studied occurred in the following sequence: rat $>$ mouse $>$ guinea pig $>$ hamster $>$ monkey.
\end{abstract}

\section{INTRODUCTION}

HUMAN chorionic gonadotrophin (HCG) has long been employed as an indicator of pregnancy in the human using target organs of various animals. A potent target receptor organ has been the ovary as used in the Ascheim-Zondek (1930) pregnancy test. More recently, the uptake of radiolabeled HCG in the rodent ovary has been described by Espeland et al. (1968) and Eshkol \& Lunenfield (1968). Hreshchyshýn \& Kazeto (1969) demonstrated that ${ }^{131}$ I-labeled HCG concentrated equally well in the ovary of the dog. Concurrently, Midgely \& Jaffe (1968) reported the biological half-life of HCG in humans using the radioimmunoassay technique. Preliminary results of ${ }^{125} \mathrm{I}$ HCG uptake in the ovary of the monkey were later described by Mizejewski et al. (1972). It was further reported that ${ }^{125}$ I-HCG concentrated equally well in the mouse theca cell carcinoma of the ovary as in the normal ovary (Mizejewski, 1972). Thus, the uptake of labeled HCG in the mammalian ovary has been well documented to date.

It becomes apparent, in view of the above studies, that the mammalian ovary may be utilized as an organ (animal) model for in vivo studies of HCG physiological activity. Since animal models are clinically employed for human pregnancy tests in many hospitals, a comparative study of HCG ovarian uptake was deemed of importance. Therefore, this study was undertaken to assess the ovarian uptake of HCG in a number of commonly used mammalian animal models.

* This work was supported in part by research funds from the Biology Department, University of South Carolina, Columbia, SC and from the VA Hospital (Part II) Research and Development Funds, Ann Arbor, MI, U.S.A.

$\dagger$ Present address: Division of Labs and Research, New York State Department of Health, Albany, N.Y. 12201, U.S.A.

\section{MATERIALS AND METHODS}

Hormone procurement

A highly purified preparation of HCG (Antuitrin-S, 1700 I.U./mg) was employed in all phases of the present study. In addition, human growth hormone (HGH) was used as a protein and trophic hormone control. Purified HCG was obtained from Parke-Davis, Ann Arbor, Michigan; HGH was supplied by Abbott Laboratories, North Chicago, Illinois.

\section{Radioiodination procedures}

Both HCG and HGH were labeled with ${ }^{125} \mathrm{I}$ by the method of Hunter and Greenwood (1962). The labeled hormones were freed from unbound iodine by gel filtration on Sephadex G-100. ${ }^{125}$ I-HCG was subjected to an additional filtration on a G-200 column to ensure homogeneity of the radiopreparation. Radioactivity counts were measured in an ionization chamber. Pooled fractions of ${ }^{125} \mathrm{I}-\mathrm{HCG}$ contained a specific activity of $78.42 \mathrm{Ci} / \mu \mathrm{g}$ and a protein concentration of $3.35 \mu \mathrm{g} / \mathrm{ml}$, while the ${ }^{125} \mathrm{I}-\mathrm{HGH}$ had a specific activity of $86.64 \mu \mathrm{Ci} / \mu \mathrm{g}$ and a protein content of $1.94 \mu \mathrm{g} / \mathrm{ml}$. The radiohormones were suspended in $0.05 \mathrm{M}$ phosphate buffer stabilized with $1.0 \%$ bovine serum albu$\mathrm{min}$. The free iodine $\left({ }^{125} \mathrm{I}\right)$ content of the stored radiopreparations were determined periodically by thin-layer radiochromatography.

\section{Antibody production}

The production of rabbit antibodies to HCG by the present investigator has already been described (Quinones et al., 1971). In brief, HCG (500 I.U./ml) was mixed with equal parts of Freund's complete adjuvant for antigen immunization. Mature male New Zealand rabbits were immunized with bi-weekly subcutaneous injections $(0.5 \mathrm{ml}$ of antigenadjuvant mixture) for an 8 week period. The animals were bled and the serum obtained 14 days after the last injection.

\section{Hemagglutination inhibition $(\mathrm{HI})$}

Sheep red blood cells preserved in Alsever's solution, were tanned with pyruvaldehyde for use in the hemagglutination 
inhibition (HI) method of Butt (1967). The pyruvaldehydetanned red cells were sensitized with $200 \mu \mathrm{gm}$ of purified HCG for 1 hr at $50^{\circ} \mathrm{C}$. Rabbit anti-HCG serum was first titrated in micro-Takasky plates to obtain a hemagglutination (HA) titer. Once the antiserum HA titer was achieved, known amounts of purified HCG were added to constant amounts of antiserum to obtain a HI titer. In this fashion the radiohormone preparations were analyzed for HCG concentrations.

\section{Biologic activity}

${ }^{125}$ I-HCG was tested for biologic activity by the methods of Albert \& Berkson (1951) and Delfs (1941). In the former method, ${ }^{125}$ I-HCG (1.5 I.U. units) was injected i.p. into six immature female $W$ istar rats and the ovaries inspected for hyperemia $6 \mathrm{hr}$ later. The Delf procedure is based on the increase in uterine weight of immature female rats over a $72 \mathrm{hr}$ period. In this method, ${ }^{125} \mathrm{I}-\mathrm{HCG}$ in six equally divided doses was administered i.p. to six immature rats over a $48 \mathrm{hr}$ period. The entire uterus of each animal was removed and weighed $24 \mathrm{hr}$ after the last injection. The concentration of HCG in I.U. was obtained from a standardized graph. The two assay procedures were repeated using six rats, each injected with comparable amounts of ${ }^{125} \mathrm{I}-\mathrm{HGH}$.

\section{Statistical procedures}

The method of averages (Simpson et al.. 1960) was used throughout the study. Discrete quantitative data was recorded as the mean, standard deviation, and standard error of the mean (SEM). Points on the bar graph were considered significant if non-overlapping occurred at 1.0 SEM $( \pm)$ value.

\section{Animal studies}

Normal intact (non-hypophysectomized) cycling, young adult Hartley guinea pigs (Cavia porcellus), golden Syrian hamsters (Mesocricetus auratus), Sprague-Dawley rats (Rattus rattus), and A7-(c57 $\times$ A) mice (Mus musculus) were used for the radioisotope tissue distribution studies. In addition, normal young adult rhesus female monkeys (Macacus mulatta), weighing $10-20 \mathrm{lb}$, were similarly employed.

Each animal, depending on size, received an i.v. injection (30-90 $\mu \mathrm{Ci}$ ) of either of the radiohormone preparations and was sacrificed at various time intervals from 1 to $18 \mathrm{hr}$ postinjection. At the time of autopsy, 12 tissues and/or organs were removed, rinsed in saline, weighed, and assayed for radioactivity in an automatic gamma well counter (Nuclear-
Chicago). Counts were accumulated for a period of time to insure less than $5 \%$ radioactive decay and machine counting efficiency. Standards of the original radiohormones were made and counted identically to the tissues. After removal the tissues were counted against a $100 \mu \mathrm{l}$ blood sample from the same animal. Organ and tissue samples were excised to approximate the weight of the blood sample and were calculated as counts per $\mathrm{min} / \mathrm{mg}$ of tissue. The results were then converted to tissue: blood (T/B) ratios. This method of data expression ( $\mathrm{T} / \mathrm{B}$ ratio) relates directly the site of localization of the radiolabeled particles. T/B values greater than unity $(>1.0)$ signify an active tissue uptake of the radio-compound, while $\mathrm{T} / \mathrm{B}$ values less than 1.0 indicates activity in the blood and the lack of tissue uptake.

In certain instances, autopsied tissues were sectioned for autoradiography to allow visual confirmation of tissue localization. Autoradiographic procedures were performed following the procedure described by Appelgren et al. (1963)

\section{RESULTS}

\section{Radioiodination of $H C G$}

Labeling of HCG with ${ }^{125}$ I with subsequent passage through Sephadex G-100 resulted in a multiphasic curve. A shoulder $(A)$ and two major peaks (B and $C$ ) were obtained in addition to the free iodine $\left({ }^{125} \mathrm{I}\right)$ peak. Fraction B, which possessed the greatest biologic activity, was rechromatographed a second time through G-200 and resulted in one uniform peak termed fraction $\mathbf{B}^{1}$. All studies described below employed the $\mathbf{B}^{1}$ fraction of HCG.

\section{Immunologic and biologic activities}

The immunologic activity of ${ }^{125}$ I-HCG was evaluated by the method of hemagglutination inhibition. With this assay method, the radiolabeled HCG concentration was found to be $30 \mathrm{I} . \mathrm{U} . / \mathrm{ml}$. Correspondingly, the biologic activity of ${ }^{125} \mathrm{I}-\mathrm{HCG}$ as determined by the Delfs uterine weight assay was $24 \mathrm{I} . \mathrm{U} . / \mathrm{ml}$. Thus, there was a close correlation between the immunologic and biologic activity (immunologic/biologic activity ratio $=1 \cdot 25$ ) of the radioiodinated $\mathrm{HCG}$ In the qualitative measurement of ${ }^{125} \mathrm{I}-\mathrm{HCG}$ biologic

Table 1. The tissue-to-blood (T/B) ratios for various mammalian organs and tissues are displayed following intravenous injection of radiolabeled $\left.{ }^{125} \mathrm{I}\right)$ human chorionic gonodotrophin (HCG) and human growth hormone (HGH)

\begin{tabular}{|c|c|c|c|c|c|c|c|c|c|}
\hline \multirow[b]{2}{*}{ Animal } & \multirow[b]{2}{*}{ Statistic } & \multicolumn{8}{|c|}{ Organs and tissues } \\
\hline & & Ovary & Kidney & Liver & Spleen & Lung & Uterus & Pituitary & Muscle \\
\hline Guinea Pig & $\overline{\mathbf{x}}$ & $4 \cdot 04$ & $2 \cdot 44$ & $1 \cdot 00$ & 0.47 & 0.32 & 0.56 & - & - \\
\hline$(2)^{*}$ & SEM & - & - & - & - & - & - & - & - \\
\hline Hamster & $\bar{x}$ & 2.68 & 1.23 & 0.47 & 0.32 & $\ldots$ & 0.92 & 0.13 & 0.13 \\
\hline (5) & SEM & 1.24 & 0.09 & 0.05 & 0.01 & - & 0.08 & 0.01 & 0.02 \\
\hline Rat & $\overline{\mathrm{x}}$ & 7.56 & $3 \cdot 12$ & $0 \cdot 37$ & 0.22 & 0.44 & 0.29 & - & 0.06 \\
\hline (4) & SEM & 2.44 & 0.18 & 0.01 & $0.0 !$ & $0 \cdot 04$ & 0.03 & - & 0.01 \\
\hline Mouse & $\ddot{x}$ & $4 \cdot 50$ & $\mid \cdot 5$ I & 0.35 & 0.34 & 0.44 & 0.67 & $(0.13$ & 0.22 \\
\hline \multirow[t]{2}{*}{$(10)$} & SEM & $1 \cdot 0.3$ & 0.14 & 0.02 & $(v+1) 2$ & 10.114 & $1+106$ & $(602$ & 0.05 \\
\hline & & \multicolumn{8}{|c|}{ Orgatus :and Iissues } \\
\hline Animal & Staltistic & Ovary & Kidney & Liver & Spleen & Lung & l:krts & Palutialy & Muscle \\
\hline Hamslẹr & $\bar{x}$ & v.55 & 233 & 0.613 & 0.67 & & 1.14 & 10.36 & $0 \cdot 20$ \\
\hline (4) & SEM & 0.04 & 0.31 & 0.04 & 0.07 & - & 0.14 & 0.03 & 0.01 \\
\hline Mouse & $\overline{\mathbf{x}}$ & 0.22 & 0.79 & 0.38 & 0.49 & 0.56 & 0.53 & 0.17 & 0.15 \\
\hline (5) & SEM & 0.03 & 0.05 & 0.03 & 0.05 & 0.04 & 006 & 0.03 & 0.04 \\
\hline
\end{tabular}

* Number in the parenthesis indicates number of animals sampled.

SEM = standard error of the mean.

$\overline{\mathbf{x}}=$ mean 
activity, the gonadotrophic function of the radiohormone was consistently demonstrated by ovarian hyperemia in immature rats. It may also be noted that ovarian hyperemia could be completely suppressed by incubation of the ${ }^{125}$ I-HCG with whole rabbit antiHCG serum prior to injection into rats. The amount of serum required for hyperemic suppression was estimated from the results of the HI assay.

Tissue distribution in animals

Mouse studies. The optimum time of assay for the tissue radioactivity distribution was found to be $3.0 \mathrm{hr}$ postinjection and this time period was used for all the mouse studies. Radioiodinated HCG is not concentrated by any organ of the female mouse with the exception of the ovary (Table 1). The ovary concentration at $3 \mathrm{hr}$ postinjection was 4.5 times that of blood (mean value) and 8-12 times greater than the concentration of radioiodine by any other tissue studied except the kidney. The high concentration of radioactivity in the kidney presumably was related to the excretory function of this organ for ${ }^{125} \mathrm{I}-\mathrm{HCG}$ and/or free iodine. The use of ${ }^{125} \mathrm{I}$ human growth hormone $(\mathrm{HGH})$ as a radiohormone control was compared to that of the ${ }^{125} \mathrm{I}$ HCG uptake. Human growth hormone was not specific for the mouse ovary or any of the other female tissues studied. ${ }^{125} \mathrm{I}-\mathrm{HGH}$ is apparently not excreted as rapidly as ${ }^{125} \mathrm{I}-\mathrm{HCG}$ as judged by the $3 \mathrm{hr}$ renal concentration of ${ }^{125} \mathrm{I}(\mathrm{T} / \mathrm{B}=1.50)$.

\section{Rat studies}

The tissue distribution assay in rats was also optimum at $3.0 \mathrm{hr}$ for the ${ }^{125} \mathrm{I}-\mathrm{HCG}$ ovarian uptake (Table 1). However, the mean T/B ratio (7.56) was considerably higher in the rat than in the mouse (7.56 vs 4.50 $\mathrm{T} / \mathrm{B}$ ratio). Kidney uptake values of the radiohormone were proportionately higher in the $\operatorname{rat}(T / B=3.0)$ than those described for the mouse. It appeared that the higher ovarian uptake signified that more radiohormone was being taken up and released by the target organ and ultimately excreted by the renal systems. As in the mouse, ${ }^{125} \mathrm{I}$-HGH was non-specific for all of the female rat tissues and organs studied. Uptake levels of ${ }^{125} \mathrm{I}-\mathrm{HCG}$ in all other tissues were unremarkable.

\section{Hamster studies}

The hamster radiouptake levels of ${ }^{125} \mathrm{I}-\mathrm{HCG}$ differed from the rat and mouse in that the optimum time of ovarian uptake was $4.0 \mathrm{hr}$ (Table 1). The concentration of radioisotope in the ovary at $4 \mathrm{hr}$ postinjection was 2.68 ( $\mathrm{T} / \mathrm{B}$ ratio) while the kidney displayed a value of $1 \cdot 20$. Again, the lesser the mean ovarian T/B ratio, the lesser the renal concentration. All other organs and tissues values were insignificant with the exception of the uterus $(\mathrm{T} / \mathrm{B}=0.95)$. However, the ${ }^{125} \mathrm{I}$-HGH uptake levels were correspondingly high in the uterus $(\mathrm{T} / \mathrm{B}=1.04)$ implying a greater receptivity than in the previous animals studied (see discussion). Renal $T / B$ ratios were also high $(T / B=2.33)$ in hamsters administered ${ }^{125} \mathrm{I}-\mathrm{HGH}$. Thus, the rate of renal excretion of $\mathrm{HGH}$ was greater than in all other rodents studied to date.

\section{Guinea pig studies}

The optimum time of ovarian uptake of ${ }^{125} \mathrm{I}-\mathrm{HCG}$ in the guinea pig proved to be $1.5 \mathrm{hr}$ postinjection (Table 2). At this time period, the T/B ratios of the ovary and the kidney were 4.04 and 2.44 , respectively. Again, the ovary-kidney relationship was borne out emphasizing the quick release of the trophic hormone from the target tissue. However, the rate of renal excretion is exceedingly high in this species and by $3.0 \mathrm{hr}$ the $T / B$ ratio in the kidney reached $3 \cdot 0$, while that in the ovary diminished to $1 \cdot 2$. Urine values (T/B ratio) were astronomically high confirming the rapid rate of excretion. Another pecularity of this species is an increased level of ${ }^{125} \mathrm{I}-\mathrm{HCG}$ in the stomach. It is conceivable, however, that these values may represent free ${ }^{125} \mathrm{I}$ released by the thyroid gland. All other organs and tissues were unremarkable concerning radiohormone uptake, except the liver which displayed a $\mathrm{T} / \mathrm{B}$ ratio $=$ 1.000 .

\section{Monkey studies}

The concentration of the ${ }^{125} \mathrm{I}$ from 1 to $5 \mathrm{hr}$ by various tissues of the rhesus monkey is depicted in Fig. 1. The tissue distribution levels of ${ }^{125} \mathrm{I}-\mathrm{HCG}$ in the monkey is qualitatively similar to that of the rodents.

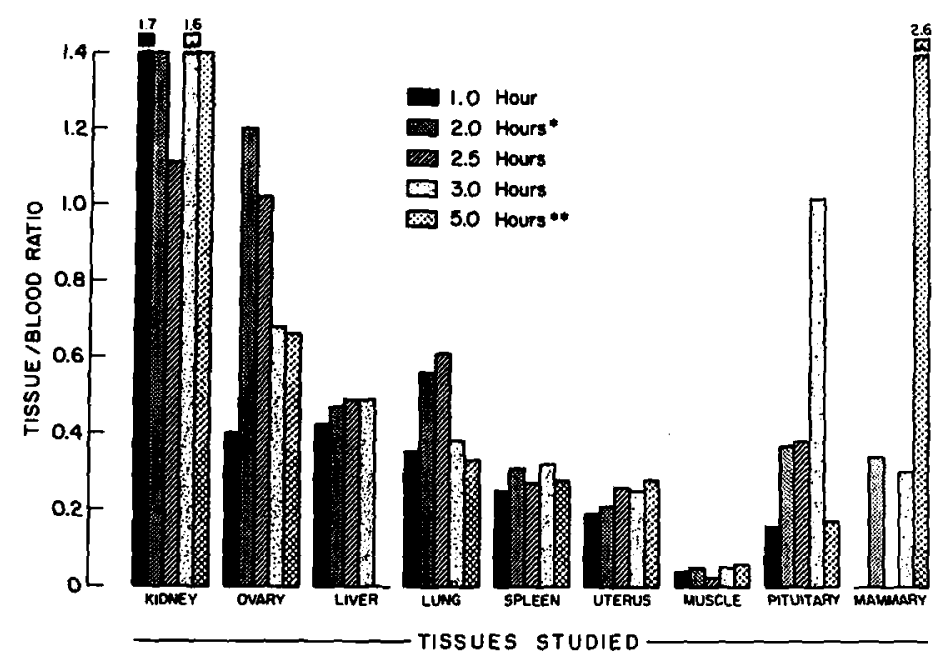

Fig. 1. Time study histogram demonstrating tissue radioactivity levels of ${ }^{125} \mathrm{I}-\mathrm{HCG}$ in female rhesus monkeys. One asterisk denotes monkey in menstruation; two asterisks signify lactating female. Each bar of histogram indicates one monkey study. 


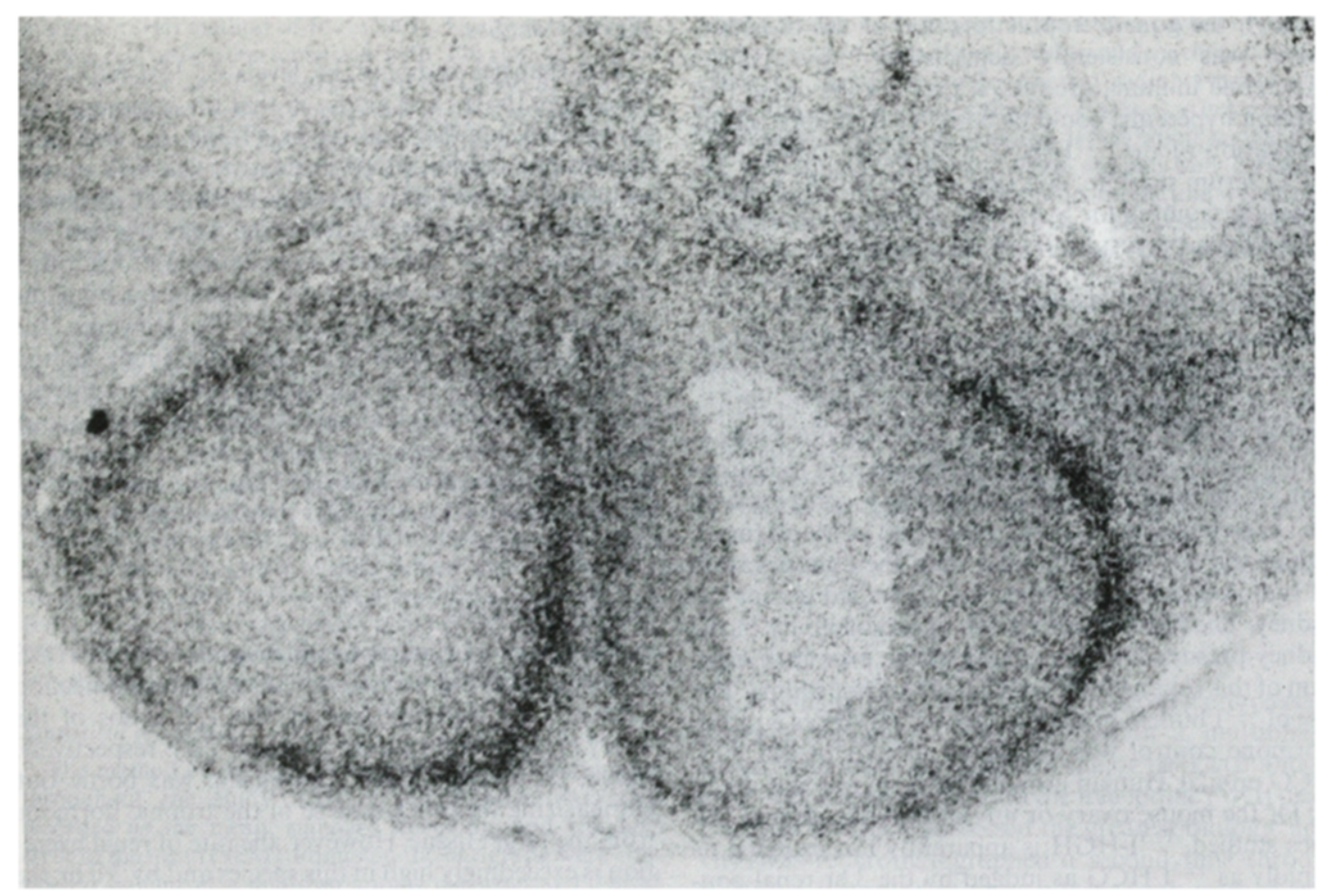

Fig. 2. Mouse tissue audoradiogram displaying dense isotopic granule distribution overlying the thecal and interstitial cells. Note the lesser granule concentration associated with the granulosal (follicle) cells, $200 X$.

However, the radiouptake level in monkey ovary is less than in mouse ovary. Optimum radiouptake was found at $2.0 \mathrm{hr}$ approximating that of the guinea pig. Uptake levels in the ovary were $1 \cdot 2$ times blood and $2 \cdot 4$ to 12 times that of non-ovarian and renal tissues. It is suspected that the uptake of ${ }^{125} \mathrm{I}-\mathrm{HCG}$ in the monkey ovary may be dependent on a particular phase of the primate menstrual cycle. As seen previously in the rodent, the primate kidney excretes the free iodine and/ or the ${ }^{125} \mathrm{I}-\mathrm{HCG}$ rapidly after administration. It may also be noted that the radioiodine uptake in the breast of the lactating female was impressive in the monkey sacrificed at $5 \mathrm{hr}$. This may be attributed to the prolactinolike function of HCG. Finally, the high pituitary uptake of ${ }^{125} \mathrm{I}-\mathrm{HCG}$ in the monkey at $4 \mathrm{hr}$ may be similar to that previously observed in the dog (see Hreshchyshyn \& Kazeto, 1969).

\section{Tissue autoradiography}

Autoradiographic analysis of the fixed tissue sections from the normal rodents served to confirm earlier observations of HCG ovarian uptake (Epseland et al., 1968; Eshkol \& Lunenfeld, 1968). The radioisotope was heavily concentrated in the thecal layers of the follicles and in the interstitium (Fig. 2). Tissue sections of guinea pig were not prepared for autoradiography. In the monkey ovary, large deposits of radioisotopic granules were not apparent; most of the granules present displayed only a light scattering. The concentration of isotopic granules in the livers of mice and monkeys was unremarkable. Therefore, at least in the rodents, the thecal elements and interstitium appear to avidly concentrate the radiolabeled HCG.

\section{DISCUSSION}

The affinity of the mammalian ovary as a target organ for radiolabeled HCG was well documented in the present report. The tissue distribution of ${ }^{125} \mathrm{I}-\mathrm{HCG}$ was patternistic and similar in all the mammals studjed. T/B ratios greater than unity were consistently recorded for the kidney in all the animal species indicating a rapid excretion of the radiohormone and/or its nuclide (i.e. ${ }^{125} \mathrm{I}$ ). All other organs and tissues failed to display any affinity for HCG. In addition, a comparable target organ could not be found in any of the animals when ${ }^{125} \mathrm{I}-\mathrm{HGH}$ was used as a radiohormone control. Finally, the optimum time for the localization of HCG in the ovary varied in all animals tested extending from 1.5 to $4 \mathrm{hr}$.

${ }^{125}$ I-HCG concentrated specifically in the ovaries of all animals tested, but the time of optimum localization varied. At 3-4 hr postinjection, the uptake of HCG in the rodents (mice, rats and hamsters) resulted in $\mathrm{T} / \mathrm{B}$ ratios from 2.68 (hamster) to 7.56 (rat) times that of blood. All other organs with the exception of the kidney (T/B) ratios $=1 \cdot 50-3.35$ ), failed to display an affinity for HCG. Occasionally, the uterus demonstrated an avidity for ${ }^{125} \mathrm{I}-\mathrm{HCG}$ (hamster) suggesting either an increased vascular supply to that organ or the presence of a cross-reacting cell receptor. The apparent affinity of HCG for the hamster uterus may also be related to an estrus cycle event. The radioconcentration of HCG in the monkey and guinea pig were somewhat less (1.09 and 4.04, respectively), with optimum uptake time at $1.5-2.0 \mathrm{hr}$ postinjection. Again, kidney uptake levels were elevated indicating a high rate of HCG excretion. Apparently, HCG is used in the 
cell for only a brief period and is excreted rapidly as demonstrated in the present report. That the rodent ovary utilizes ${ }^{125} \mathrm{I}$-HCG for only a brief duration has been documented in prior reports by Epseland $e t$ al. (1968) and Eshkol \& Lunenfield (1968).

The affinity of ${ }^{125} \mathrm{I}-\mathrm{HCG}$. for the various mammalina ovaries studied occurred in the following sequence: rat $>$ mouse $>$ guinea pig $>$ hamster $>$ monkey. This varied affinity of the mammalian ovary for HCG is quite interesting and has both academic and practical ramifications. These data suggest a cell receptor differential among the various animals tested. This difference may be reflected either in the: $(A)$ receptor cell numbers involved, (B) the number of the receptor molecules per cell, or $(\mathrm{C})$ in the receptor cell thresholds levels. The receptor cells for HCG in the rodents have not been clearly defined but appear to be the interstitial and thecal elements (Falck et al., 1962; Mizejewski, 1972). The present autoradiographic data supports these prior reports. Baird (1972) proposes that these cell populations provide a "permanent" corpora lutea in these animals (rodents). Involvement of the interstitial cells would naturally provide an enormous number of cells per organ suited for the uptake of HCG. Hence, it is not surprising that the mouse and rat are still employed as the animal models (pregnancy tests) of choice at many clinical centers. However, it should be noted that the immature mouse or rat is employed for the pregnancy tests to avoid conflicting results due to changes during the sexual cycles. The immature rat is even more sensitive than the adult as evidenced by the brief incubation time of the ovarian hyperemia test.

The cell receptor for HCG in the mammalian ovary has been a center of controversy for many years. The autoradiographic evidence presented in this report showed isotopic granule distribution in the thecal envelopes of the rodent ovarian follicles and in the interstitium. However, comparable findings could not be demonstrated in the non-rodents (monkey). It is conceivable that the HCG-receptor cell in the primate is not the same as in the rodent. This might be considered in light of the longer length of the sexual cycle (menstrual vs estrus) subsequently producing extended periods of estrogen or progesterone cell stimulation. Therefore, such differences could be due to the local hormonal influence under which the ovarian receptor cell is subjected as suggested by Ryan \& Smith (1965). In the rodent, stimulation of the ovary by HCG leads to changes suggesting the production of weak androgenic steroids, i.e., androstenedione. Except during pregnancy, it is not known whether such metabolic byproducts would be similarly produced by the primate following HCG stimulation. It may be that the human pregnancy test employed in the rodent for many years has a completely different physiological basis than in the cycling primate.

\section{SUMMARY}

The use of the mammalian ovary as a target organ for human clorionic gonadotrophin (HCG) was studied in the present report. HCG was labeled with ${ }^{125} \mathrm{I}$ and monitored for radioactivity in an ionization chamber. The radiohormone was chemically defined by gel filtration via two passages through Sephadex G-
100. The labeled HCG proved to be both biologically and immunologically active.

The target organ for ${ }^{125} \mathrm{I}-\mathrm{HCG}$ localization was the mammalian ovary as evidenced by tissue-to-blood ratios. Radiolabeled HCG was not concentrated by any other of the mammalian female organs and tissues except the kidney. The high concentrations of radioactivity in the kidney presumably were related to the excretory function of this organ for ${ }^{125} \mathrm{I}-\mathrm{HCG}$. Finally, a comparable target organ could not be found in any of the animals when ${ }^{125} \mathrm{I}-\mathrm{HGH}$ was used as a radiohormone control.

Acknowledgements-The author expresses his deepest appreciation to Mr. Glenn Walterink and Ms. Jennifer Baron for their technical assistance.

\section{REFERENCES}

Albert A. \& Berkson J. (1951) A clinical bio-assay for chorionic gonadotrophin. J. clin. Endocr. 11, 805-820.

Appelgren L. E., Soremark R. \& Ullberg S. (1963) Improved resolution in autoradiography with radioiodine using the extranuclear electron radiation from ${ }^{125} \mathrm{I}$. Biochim. biophys. Acta 66, 144-149.

ASCHHEIM S. (1930) The early diagnosis of pregnancy, chorioepithelioma. and hydatidiform mole by the AschheimZondek test. Am. J. Uhstet. Gynec. 19, 335-342.

BAIRD D. T. (1972) Hormones in Reproduction (Edited by AUSTIN C. R. \& SHORT R. V.) Vol. 3, pp. 1-28. Cambridge University Press, Great Britain.

BUTT W. R. (1967) The Chemistry of the Gonadotrophins. pp. 107-108, Charles C. Thomas, Springfield, Illinois.

Eshrol A. \& LUNENFELD B. (1968) Fate and localization of iodine-labeled HCG in mice. In Pharmacology of Hormonal Polypeptides and Proteins. Advances in Experimental Medicine and Biology (Edited by BACK N., MARTINI L., Paolettr R.) Vol. 2, pp. 223-228, Plenum Press, New York.

Espeland D. H., Naftolin F. \& Paulsen C. A. (1968). Metabolism of labeled ${ }^{125}$ I-HCG by the rat ovary. In Gonadotrophins, (1968) (Edited by RosENBERG E.) pp. 187191, Geron-X, Los Altos, Mexico.

DeLFS E. (1941) An assay method for human chorionic gonadotrophin. Endocrinology 28. 196-202.

Falck B., Menander K. \& Nordanstedt O. (1962) Androgen secretion by the rat ovary. Nature, Lond. 193. 593-594.

HREShCHYShyn M. M. \& Kazeto S. (1969) Ovarian scan with human chorionic gonadotrophin ${ }^{131}$ I. Am. J. Obstet. Gynec. 103, 434-436.

Hunter W. M. \& Greenwood F. C. (1962) Preparation of iodine-131 labeled human growth hormone of high specific activity. Nature, Lond. 194. 495-496.

LUNENFELD B. \& ESHKOL A. (1967) Immunology of human chorionic gonadotrophin (HCG). Vitamins and Hormones 25, 137-190.

MIDGLEY A. R. \& JAFFE R. B. (1968) Regulation of human gonodotrophins-II. Disappearance of human chorionic gonodotrophin following delivery. J. clin. Endocr. 28, 1712-1718.

MizejeWSKi G. J., Beirerwaltes W. H. \& Quinones, J. (1972a) Uptake of radioiodinated human chorionic gonodotrophic hormone by ovarian carcinoma. J. Nuclear Med. 13, $101-106$.

MiZEJEWSKI G. J. (1972b) Selective gonadotrophin uptake by mouse ovarian carcinoma. Experientia 28, 961-962.

QUiNONES J., Mizejewski G. \& Beierwaltes W. (1971) Choriocarcinoma scanning using radiolabeled antibody to chorionic gonadotrophin. J. Nuclear Med. 12. 69-75. 
Ryan K. J. \& SMITH, O. W. (1965) Biogenesis of steroid hormones in the human ovary. In Recent Progress in Hormone Research (Edited by PINCUS G.) pp. 367-409.

Simpson G. G., Roe A. \& Lewontin R. C. (1960) Quantitative Zoology, pp. 172-178, Harcourt, Brace, Iovanovich, Academic Press, New York. 